\title{
Academic Impact of Global Ranking of Higher Education Institutions in Kosovo
}

\author{
Prof. Dr. Armand Krasniqi \\ Faculty of Economics, \\ University "Hasan Prishtina", Prishtina
}

Doi: 10.36941/jesr-2019-0026

\begin{abstract}
Globalization in higher education has highlighted the obligation to provide information on the level of academic quality provided by higher education institutions. This has resulted in the design of university ranking systems, respectively in creating of global and regional ranking tables. This information can and should be a contribution to the advancement of quality education in the country. Kosovar institutions that are competent in this field should show the courage to, in addition to providing information from international rankings, establish a credible national system for providing data, respectively the ranking list of higher education institutions in the country. This may help to identify important issues and information that will serve to create sustainable academic policies. This paper is exclusively based on empirical data provided by a questionnaire. As such it analyzes whether the ranking of higher education institutions in our country are needed and what will be the impact of academic quality measurements. These data enable the country's institutions to measure the public interest in the rate and dynamics of higher education development in the country, identifying the direction of university development. In these circumstances there should be no doubt about the obligation to provide this data, and only on the basis of it, the harmonization of public policies and legislation on quality in education and its role in the market.
\end{abstract}

Keywords: education, HEls, quality, ranking, market, institution

\section{Introduction}

Rankings or comparisons regarding the identification of the degree of quality offered by Higher Education Institutions (hereinafter HEls) within a given higher education system were first implemented in the United States during the 1870s. - 1890s. During this time period, the U.S. Bureau of Education classified the educational institutions. After that, some similar rankings are recorded, but only in the US (Goldin \& Katz, 1999). Unlike the efforts outlined above, on a global scale, university rankings are a relatively new phenomenon. In reality they officially appeared in 2003 with the introduction of the Shanghai rankings. This process was motivated and built by the goal of defining the position of Chinese universities compared to other world-renowned universities. For the global public, the first results were startling, especially in European circles, as US universities dominated the Top 20 and Top 100 (Yan, 2010).

The rank list authors determine the indicators, the calculation methods and the relative measures factors. So every ranking at its core is "subjective".

According to the authors of the rankings, from year to year some of the methodologies change, the measures of individual indicators are corrected, so that they are as objective as possible. These rankings, which are now developing at a fast pace, usually treat HEls as highly sensitive processes since the amplitudes of sudden ups and downs in the list produce serious impacts. There are three university rankings systems in the world that take a global approach (Yan, 
2010). These systems are QS "World University Ranking"; Times Higher Education; Academic Ranking of World Universities (ARWU) - is often referred to as rankings of "Shanghai Jiao Tong" (as the data is processed by a unit at Shanghai Jiao Tong University). The results of global rankings often become the subject of certain debates and misinterpretations since published data are generally considered to have no relevant value of the indicators used but are only perceived as a percentage of one institution's "success" compared to another better ranked. Some rankings use absolute values of indicators (eg total number of publications), which is more consistent with large institutions, while others use relative values (number of papers published by academic staff) corresponding to the top universities. small but more productive (Soh, 2017).

Recentrly also in Kosovo, the rankings of universities have attracted the attention of public, political, scientific and academic circles. Particularly in the last two or three years the results of the World Higher Education Carriers ranking published by Webometrics have stirred debate in almost all segments of social life. In this platform, as in other platforms, certain bibliometric elements as the number of publications and their citation are crucial. These rankings suggest a similar simplicity for the evaluation of scientific performance. The immediate observation that the most popular American universities take the lead reinforces these suggestions. But things are not so simple.

The role and importance of the Standards and Guidelines for Quality Assurance in the European Higher Education Area (ESG/SUE) adopted by the Ministers responsible for higher education since 2005, following a proposal prepared by the European Association for Security of Quality in Higher Education (ENQA) in collaboration with the European Students Union (ESU), the European Association of Higher Education Institutions (EURASHE) and the European Universities Association (EUA) (ENQA, ESU, EUA, \& EURASHE, 2015).

Duhet përmendur rolin dhe rëndësinë që kanë Standardet dhe udhëzimet për sigurimin e cilësisë në Hapësirën Evropiane të Arsimit të Lartë (ESG/SUE) të miratuara nga ministrat përgjegjës për arsimin e lartë që në vitin 2005, pas një propozimi të përgatitur nga Asociacioni Evropian për Sigurimin e Cilësisë në Arsimin e Lartë (ENQA) në bashkëpunim me Unionin e Studentëve Evropian (ESU), Asociacionin Evropian të Institucioneve të Arsimit të Lartë (EURASHE) dhe Asociacionin e Universiteteve Evropiane (EUA) (ENQA, 2015). Countries that intend to be part of the EU must take into consideration these acts.

\section{Higher education in the Republic of Kosovo}

Higher Education in the Republic of Kosovo is a public service or a public good. As such it has a mission to respond, adapt and anticipate changes in the country's labor market and development. In the last two decades of social and economic transition, Higher Education in Kosovo has been moving towards a mass mobilization despite its limited capacity and opportunities. Althought the abovementioned importance the educational policy in our country was not analyzed, planned, or positioned sufficiently on the basis of a realistic prospect. This phenomenon has led to a drastic decline in the quality of education, rather than the expected improvement.

The rapid development of this system, the opening of some public universities and the almost liberal policies of opening private colleges were not accompanied by the expansion and establishment of control and enforcement mechanisms, negatively affecting the quality of the system. ${ }^{1}$ In these years, the profiled and less professional programs gradually lost their relevance to the needs of the market, while the programs in the fields of Education, Economics, Law, Politics etc. became more massive. Continuously in these two decades, based also on the $2018 \mathrm{EU}$ Summary Report on Kosovo Education, the issue of quality remains the most controversial element that leaves much to be desired.

It is not disputed the fact that the quality assurance system is the responsibility of the

\footnotetext{
${ }^{1}$ Kosovo has the highest number of Higher Education Institutions and students per capita in Europe. Currently there are 39 accredited Higher Education Institutions, nine of which are public and 30 private. The number of students has increased from 40,000 in 2004 to 122,000 in 2015/2016. The rapid increase in the number of enrolled students has also contributed to the need to open new public universities.
} 
Accreditation Agency in cooperation with the Accreditation Council. However, the lack of a law on this institution and the development of fragmented evaluation procedures and criteria, the relatively slow shaping of this system, without excluding the political implications of the rapid growth and expansion of institutions and study programs, turned out to be problematic. Evaluation and accreditation processes only began to have their effects after a large proportion of institutions and programs in the private system were only licensed by the MEST.

In fact, MEST, during this period, had a passive role towards the legal obligations provided by the Law on Higher Education and as an institution responsible for the implementation of legal obligations in higher education has "forgetten" the competence to undertake the necessary policies in function of quality assurance.

There is no doubt that MEST's institutional mechanisms have been relatively well focused in respecting organizational, financial, academic and staff autonomy but, in our opinion at least, there is a lack of more effective quality control. On the other hand, the internal and external quality assurance system of HEls is characterized by problems and difficulties that are primarily related to the awareness and interest in internal quality. To the abovementioned factors is inclused aslo the unclear and confusing division of activities and competencies in internal and external quality assurance between HEls, the quality system, accreditation institutions and decision-makers such as MEST, etc.

Therefore, it should be noted that the rapid development of the system was not followed by the expansion and establishment of control mechanisms, the amendment of legislation and all this negatively affect the quality assurance of the system.

It is clear that university autonomy does not mean disrespecting regulations. We are witnessing that in the name of autonomy the following are exceeded and violated: the legal basis for the administration of the HEls; legal basis in recruiting academic staff; legal basis in dealing with employees. Abuse of autonomy status extends to the electoral system as well.

However, the MEST should provide an appropriate structure in which universities can fulfill their mission in the best possible way. But, at least so far MEST has not put in place the proper mechanisms to control academic quality efficiently and appropriately for all HEls as well as in terms of verifying their functioning and legality in terms of fulfilling the obligations sanctioned by the applicable legal and subordinate legal acts, regarding the institutional standards and their constituent units.

The study is focused on promoting the idea that higher education institutions must take urgent action to ensure a credible evaluation system on the basis of a national ranking. This is because even the world's leading universities believe that rankings help preserve and build the institution and its reputation (Waddock, 2008). Many students in the world use university rankings to get a clearer picture of them, such as accreditation, funding, teacher recruitment, etc.

Of course, it is difficult to determine which of these ranking systems would eventually be best implemented in our country as each of them have different methodological approaches to data acquisition and processing. But the common thing is that in the latest ranking of the top 100 universities, 66 of them are American and British, while European and Asian universities are less represented by this ranking (Khan, 2017).

On the other hand, there are many reasons why HEls in the Republic of Kosovo should be included in the national ranking and wider. It is precisely on this paper that we have attempted to prepare a questionnaire that guarantees accurate data on academics' perceptions, knowledge, need, academic commitment, readiness and expectations for developing a ranking system as a very reliable information security and control mechanism of quality(Pijano, Scott, \& Knight, 2014).

We strongly believe that this data can and should be used by the government in its policy orientation for the further development of higher education, by institutions seeking international partners and by prospective students themselves (Hénard \& Mitterle, 2008), especially for students looking for a place to study, where they often refuse to study at Kosovar universities and colleges because of a lack of rank. 


\section{Survey Result}

\subsection{Methodology}

The questionnaire was distributed to public and private institutions of higher education in the Republic of Kosova, respectively to internal academic staff of these institutions. From the obtained results we estimate that the sample selected was representative and the data processed below have a high degree of reliability. A total of 111 questionnaires were collected, of which $52 \%$ in public universities and $48 \%$ in private colleges. Individual characteristics of the respondents resulted in $58 \%$ male and $42 \%$ female. In terms of their academic engagement $63 \%$ have a work experience of 1 to 10 years, $19 \%$ to 20 years of work and $18 \%$ with over 20 years of academic engagement. In terms of scientific titles, $36 \%$ of them have completed doctoral studies, $27 \%$ are undergoing doctoral studies and $37 \%$ have completed master's degrees. According to the academic title, 6\% of the respondents are Prof.Dr., 9\% Prof.Assoc., 25\% Prof.Ass., 18\% Lecturers and the rest $42 \%$ teaching assistants. Analyzed by the managerial level of the academic staff respondents it was found that $14 \%$ of them are senior management, $22 \%$ middle management, $7 \%$ lower management and $57 \%$ of respondents do not have managerial positions.

\subsection{Result}

Regarding the question if the respondents have information about the global ranking platforms $78 \%$ have informationa, $14 \%$ have insufficient information and $8 \%$ have no information. In terms of their opinion on whether the data elaborated and published by Webometrix is useful or not for the ranking of Higher Education Institutions , $76 \%$ gave positive answer, $12 \%$ negative and $12 \%$ answered with I don't know. If they were satisfied with their University / College ranking score on these platforms, $47 \%$ of the respondents answered yes, $27 \%$ gave negative answers and only $26 \%$ of them were partially satisfied.

When it comes to the questions if there are debates or discussions about the ranking position of their institution on WEBOMETRICS or any other platform, $46 \%$ answered yes, $33 \%$ no and $21 \%$ rarely.

On the question that according to the information they have, where does the WEBOMETRICS platform rank is based, according to table no. $1,71 \%$ think in teaching, $14 \%$ in research, $7 \%$ in citations, $8 \%$ in international perspectives, and with $0 \%$ answer is Alumni and others.

Table 1:

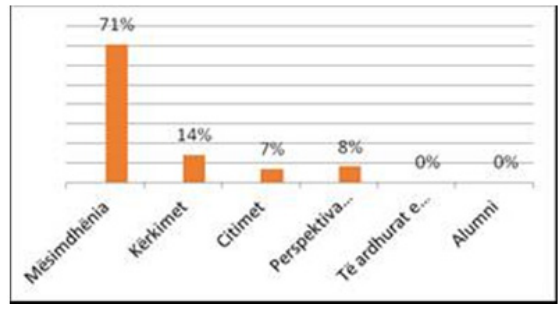

Table 2:

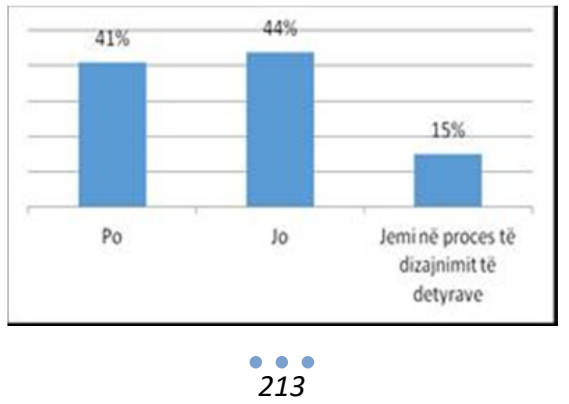


In order to identify how well the academic staff is motivated by the institution to improve its position in WEBOMETRICS, or whether if there is a specific attitude, strategy or document in this regard, the results in Table 2 shows that $41 \%$ respondents answered yes, $44 \%$ answered no and $15 \%$ stated that they are in the process of designing tasks.

Respondents' opinion if MEST's should start creating the legislation to ensure and implement a National-Ranking System Platform, based on statistics in tables no. 3, it was found that $78 \%$ of the respondents answered yes, $14 \%$ no and $8 \%$ did not know.

\section{Table 3:}

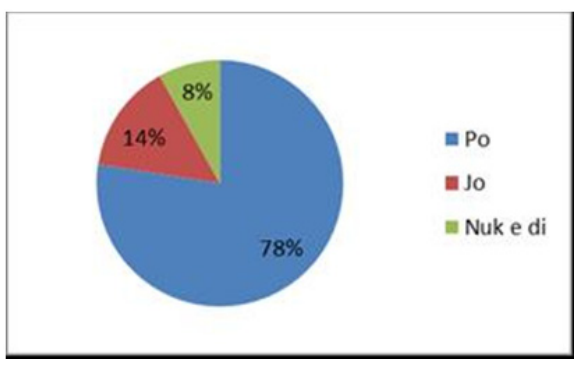

Meanwhile, from the results in the following table we see that to the question on who should develop the HEI ranking process, $52 \%$ of respondents think that this should be developed by international agencies or institutions that have the credibility and capacity needed to develop this process, $39 \%$ of them think that MEST should develop it through the establishment of an independent national agency (like the Kosovo Accreditation Agency), with a special mission for national ranking, and $9 \%$ of them think that Higher Education and its providers do not need such an institution.

\section{Table 4:}

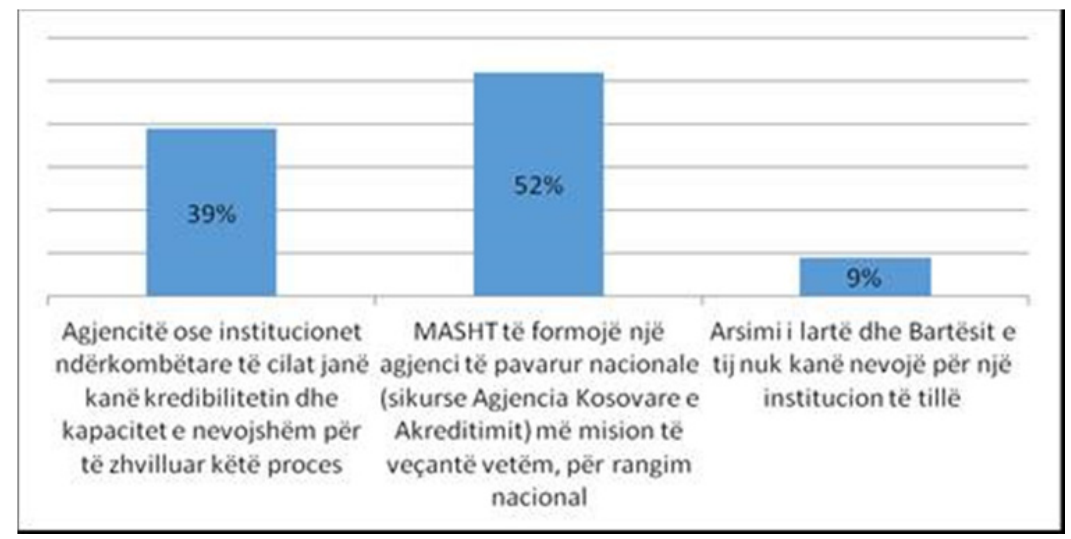

In table no. 5, when asked if a HEls ranking process would take place in the Republic of Kosovo, who should be included, $38 \%$ of the respondents think that the ranking of Universities or Colleges should be included, $31 \%$ think that only the Faculty ranking list should be included regardless of which University or College they belong to and $31 \%$ of them think that it should be included only program rankings, regardless of which University / College or Faculty they apply to.

Regarding the timeframe of developing national rankings (table no. 6), it turned out that $41 \%$ of respondents think that this ranking should be every 2 years, $31 \%$ every 1 year and $28 \%$ should be 3 years. year. 
Table 5:

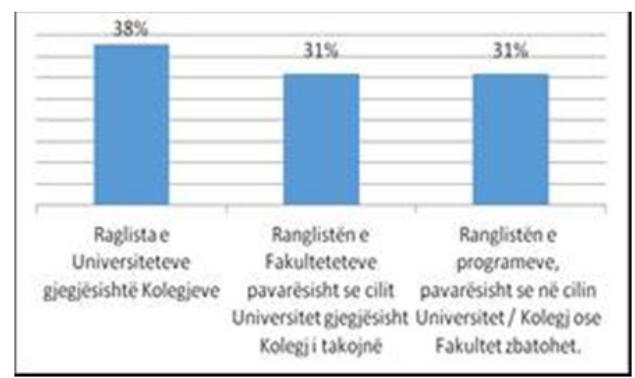

Table 6:

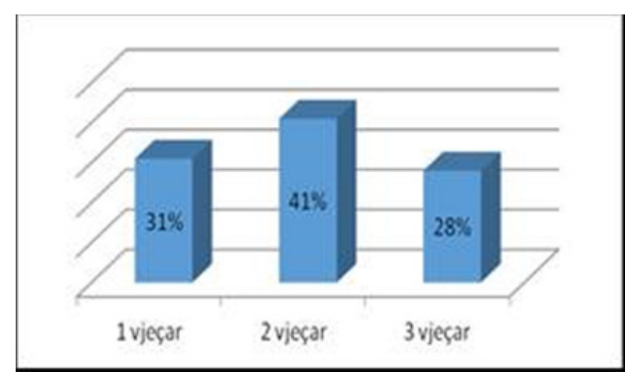

If in the Republic of Kosovo it was decided to develop the HEI ranking process, would the data from this process be sufficient arguments to ascertain the development situation and perspective of your institution? According to the results in table no. $7,51 \%$ of the respondents answered with partial answer, $48 \%$ with yes and only $1 \%$ gave negative answer.

\section{Table 7:}

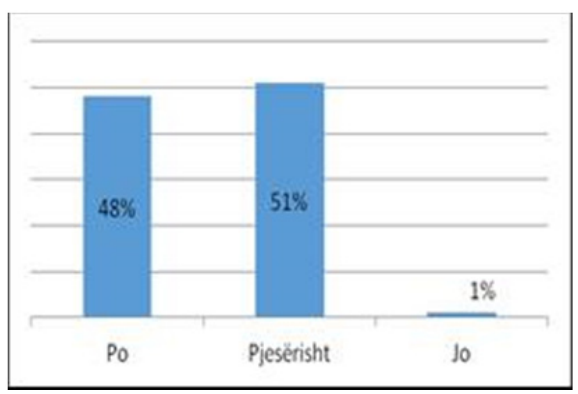

\section{Table 8:}

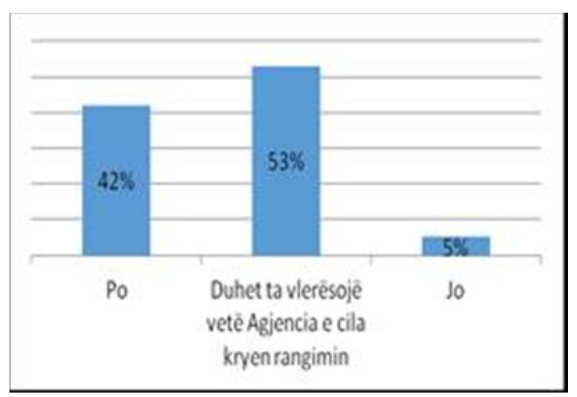


The ranking process of HEls in Kosovo, if developed by a credible agency, should specify other elements related to ranking and study sciences nature except the standarized information resources? From table no. 8 , it results that $51 \%$ of the respondents think that this should be assessed by the ranking agency, $42 \%$ think yes and $5 \%$ think no.

To te question if it is decided to establish an agency that will rank the HEls in the Republic of Kosovo (Table no. 9), $66 \%$ of respondents think that this will positively impact teaching, $13 \%$ of them think that this will improve the scientific research, $4 \%$ in citations, $6 \%$ in quality program development, there is no response to staff and student mobility and $6 \%$ of them think that this would positively impact competition between HEls in the Republic of Kosovo

Table 9:

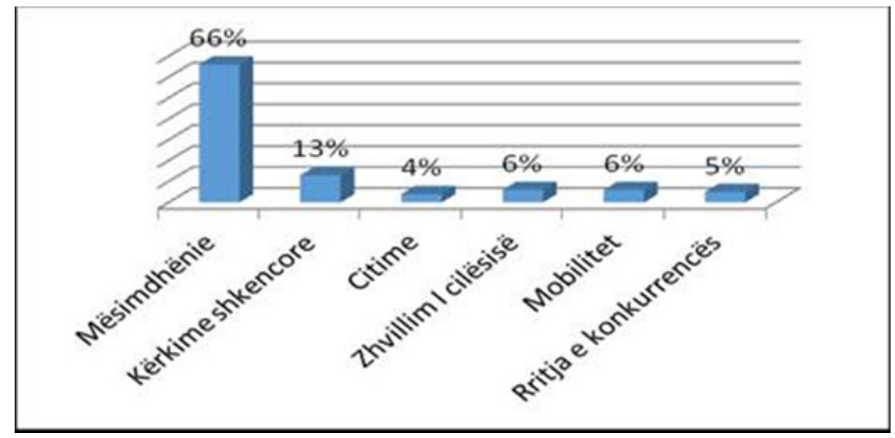

\section{Review of Empirical Data on the Outcome}

The findings from the data presented above are more or less what we have been approximately expected. Initially, it is worth noting that the majority of respondents are of the opinion that MEST should, without delay, take measures to enforce a serious rank of HEls. The reasons for this are many and one of them relates to the fact that currently HEls are in a horizontal line, none of them knows enough to argue which of them is more advanced then the other and which has a lower rank. Also, the results show that HEls in Kosovo are aware and have many reasons to be involved in a national ranking process and beyond.

It is likely that HEls, receiving the evaluation from an independent international agency contracted by MEST, will be able to better understand their strengths and weaknesses (Tremblay, Lalancette, \& Roseveare, 2012). Respondents largely emphasized that rankings have real effects on what HEls value and how they work. In giving their opinions they are aware that HEls may not be "good enough" or "nearly equal". Of course under the competition conditions, some should or are better than others. The HEls rankings create student independence, where they can use this information to carefully determine which university / college or institution they want to attend (Bakhradnia, 2016). All this not only to fosters the competition but also is in the function of quality regulation in the national market and beyond. It undoubtedly and strongly emerged that the eventual ranking process could be very useful for monitoring Higher Education Institutions from the competent governmental institutions.

In this way it was argued that ranking HEls is expected to be a very important and efficient process, not only because it helps students in their decision making, but also it facilitates the work of employers as they will have a better picture on what employees to recruit. The ranking results can also be used by government institutions and their higher education policies, including institutions seeking international partners and prospective students from abroad. Students looking for a place to study where they often refuse to study at designated universities / colleges due to lack of ranking. It should be noted that the processed results showed that the majority of respondents have fragmentary information on the elements, i.e the standardized factors used to evaluate the HEls. 


\section{Conclusions}

The main responsibility for the slowdown of the development of higher education in the Republic of Kosovo and for the lack of quality control in this segment, is competent governmental institutions which are lagging behind in this regard. In Kosovo, so far no efforts have been made to make some sort of HEls ranking, this is done only at the level of accreditation of Higher Education Institutions. It is necessary to take certain measures to move HEls towards the European future. In this respect it is necessary to provide diagnostic information and case measures and information provided through the rankings that credible agencies around the world make to higher education institutions for the quality of education programs or even the infrastructure and facilities offered.

Competent government institutions should view the national ranking of HEls as an equal and complementary process to that of accreditation but with specific functions and duties. As such, rankings should be performed by international agencies with a certain degree of credibility in order to consider the results respectively the information provided as accurate, valid and unambiguous (Hénard \& Mitterle, 2008) MEST should, without delay, prepare for the national ranking process. This is due to the fact that the results of the questionnaire showed that the academic staff at HEls do not have complete information on this process. A preparatory and informative activity will guarantee equality, competition, preparation of information, etc. in order to make the ranking as credible as possible.

This information provided with a transparent process will be an indisputable help for students and stakeholders to make an important decision in life where they want to study. It is the task of the $\mathrm{HEls}$ to ensure full transparency of what they offer, etc. and inform the public about the quality level for each of them. Ranking information is also valuable to the managerial levels of HEls as they have the results of an objective evaluation by a foreign agency, out of interest and consequently faced with recognizing weaknesses and advantages, as well as what to do in the future to enhance the quality.

Such a ranking process, carried out very accurately and professionally by a credentialing agency, will for the first time make it possible to have a status analysis and assessment of study programs making them available electronically in MEST website, AAK and HEls itself, which will serve for future students to make their own choices (Sanoff, 2007).

The process of ranking HEls can also have a positive effect on affirming the need to establish other control and accountability mechanisms in order to increase quality and accountability.

\section{References}

Bakhradnia, B. (2016). International university rankings: For good or ill?

ENQA, ESU, EUA, \& EURASHE. (2015). Standards and Guidelines for Quality Assurance in the European Higher Education Area.

Goldin, C., \& Katz, L. F. (1999). The Shaping of Higher Education: The Formative Years in the United States, 1890 to 1940. Journal of Economic Perspectives, 13(1), 37-62.

Hénard, - Fabrice, \& Mitterle, A. (2008). Governance and quality guidelines in Higher Education - A review of governance arrangements and quality assurance guidelines.

Khan, - Ateek. (2017). QS World University Rankings by Subject.

Pijano, C. V., Scott, P., \& Knight, J. (2014). The State of Higher Education.

Sanoff, - Alvin P. (2007). The U.S. News College Rankings: A View from the Inside,. College and University Ranking Systems: Global Perspectives and American Challenges, Institute for Higher Education Policy.

Soh, K. (2017). World University Rankings -Statistical Issues and Possible Remedies. In Singapore Centre for Chinese Language.

Tremblay, K., Lalancette, D., \& Roseveare, D. (2012). Assessment of Higher Education Learning Outcomes Feasibility.

Waddock, - Sandra. (2008). Building a New Institutional Infrastructure for Corporate Responsibility. Academy of Management Perspectives, 22(3).

Yan, yan L. (2010). Impact of Globalization on Higher Education: An Empirical Study of Education Policy \& Design of Design Education in Hong Kong. International Education Studies, 3(4). 